\title{
Giving Religion a Place in Development Cooperation: The Perspective of Belgian NGOs
}

Ignace Pollet, Benjamin Steegen \& Idesbald Goddeeris

To cite this article: Ignace Pollet, Benjamin Steegen \& Idesbald Goddeeris (2020): Giving Religion a Place in Development Cooperation: The Perspective of Belgian NGOs, Forum for Development Studies, DOI: 10.1080/08039410.2020.1808525

To link to this article: https://doi.org/10.1080/08039410.2020.1808525

曲 Published online: 20 Aug 2020.

Submit your article to this journal $\pi$

Q View related articles $\sqsubset$

View Crossmark data $[\pi$ 


\title{
Giving Religion a Place in Development Cooperation: The Perspective of Belgian NGOs
}

\author{
Ignace Pollet ${ }^{\mathrm{a}}$, Benjamin Steegen ${ }^{\mathrm{b}}$ and Idesbald Goddeeris ${ }^{\mathrm{b}}$ \\ ${ }^{a}$ HIVA, Katholieke Universiteit Leuven, Leuven, Belgium; ${ }^{b}$ Arts, Katholieke Universiteit \\ Leuven, Leuven, Belgium
}

\begin{abstract}
Since the early 2000s an increasing number of publications has led to the emergence of a new research field: religion and development. Much of the literature focuses on defining and classifying faith-based organizations, and attributes distinctive characteristics and comparative advantages to religious actors in contrast to their secular counterparts. In line with more empirically oriented research, this article examines how eight Belgian NGOs perceive the importance of incorporating religion in their own development practice. The NGOs' narratives highlight a number of benefits and drawbacks related to their own religious profile and/or taking into account religious aspects of the context in which they work. While these narratives generally correspond with benefits and risks mentioned in the literature, their ground-level detail adds nuance and questions the validity of a clear-cut dichotomy between faith-based and secular NGOs, and the instrumentalizing language of comparative advantages. To achieve insight into the various, complex and specific ways in which religion is present in development, a deeply empirical, contextualized approach is needed.
\end{abstract}

Keywords: religion; development; development cooperation; faith-based organization; NGO; civil actors

\section{The rise of 'religion and development'}

During the last decades of the previous century, spirituality and religion were given so little attention in development circles, that Ver Beek (2000) described them as 'development taboos'. Pioneering the subject, World Development published a special issue on religion and development (Wilbur and Jameson, 1980). Almost one decade later, Quarles van Ufford and Schoffeleers (1988) dedicated an edited volume to combining development studies with anthropology of religion. It took another decade before the president of the World Bank and the Archbishop of Canterbury put the issue on the agenda of development agencies by initiating the Development Dialogue of Values and Ethics in 1998 (Marshall, 2001).

As shown by a detailed bibliography for the period 1980-2015 (Swart and Nell, 2016), religion and development became a research field in its own right from the early 2000s onwards. An exponential surge of scientific publications proved that the 
'development taboo' had been broken (Jones and Petersen, 2011). For example, since 2003 most years have seen the publication of at least one edited volume and/or special issue on the topic. A turning point was the research programme Religions and Development that ran from 2005 to 2010 at the University of Birmingham, funded by DFID (Rakodi, 2011; 2012). Similar programmes emerged at the Berkley Centre for Religion, Peace and World Affairs at Georgetown University, Washington DC, the Dutch Knowledge Centre on Religion and Development (Dalton, 2013), and the Asia Research Institute at the National University of Singapore. In addition, a number of donors and UN agencies put the topic on their agenda (e.g. Karam, 2012; 2014), and at least two international handbooks were published, compiling contributions by specialists in the field (Clarke, 2014; Tomalin, 2015). Presently, Routledge is publishing a substantial number of monographs and edited volumes in its Research in Religion and Development series, focusing on religion and development in various cultural contexts and religious traditions (e.g. Freeman, 2019; Leer-Helgesen, 2019; Rajkobal, 2019; Rakodi, 2019).

A number of reasons have been suggested for this renewed interest. Firstly, the increased attention for 'political Islam', and the mixing of military and humanitarian action during the 'war against terror' may have bombarded religion into the development paradigm (Benthall and Bellion-Jourdan, 2009). Secondly, the recognition that the secularization process witnessed in Europe and in large parts of the global North has not taken place elsewhere, has prompted questions regarding the relationship between modernization, development and religion (Carbonnier, 2013; Deneulin and Rakodi, 2011). In the global South, religion is central in the public and private sphere, and is expected to gain even more importance (PEW Research Center, 2015). This concern for religion as an integral part of a 'good life' for many people in the Global South, has also surfaced in development studies and practice. More participative approaches created openings for aspects found important by Southern stakeholders, such as culture and religion (Narayan et al., 2000; Rakodi, 2011). Thirdly, faith-based organizations (FBOs) have gained recognition as major actors in humanitarian aid and development cooperation. For example, the World Bank estimates that FBOs are responsible for the provision of half of health care and educational services in Africa (Deneulin and Bano, 2009), similar to Muslim civil society organizations in the Middle East (Le Moigne and Petersen, 2016). International development actors have discovered such locally oriented religious development organizations as partners with a potentially large outreach and impact (Clarke and Ware, 2015).

Within the literature on religion and development, a surprising amount of attention has been given to attempts to define and classify FBOs, and in identifying their distinctive characteristics and place in the development field, in comparison to their secular counterparts (e.g. Clarke and Ware, 2015; Le Moigne and Petersen, 2016; Occhipinti, 2015; Thaut, 2009; Tomalin, 2012; an extensive overview is provided by Fountain and Feener, 2017, pp.2-3). However, this narrow focus on 
taxonomy, and the problematic dichotomy between 'secular' and 'faith-based' development, have been criticized for essentializing and instrumentalizing religion, upholding normative assumptions about both religion and development, and accommodating technocratic development discourses (ibid.; Fountain and Petersen, 2018, pp.416-417; Jones and Petersen, 2011; Tomalin, 2013, p.205).

Another major strand of research consists of case studies, both in the form of monographs (e.g. Bornstein, 2003; Huang, 2009; Scherz, 2014) and edited volumes (e.g. Fountain et al., 2015; Ware and Clarke, 2016). Often critical in nature, such research provides an empirical, on-the-ground understanding of the entanglements of religion and development in specific times, places and cultural contexts. While ethnographies of FBOs in particular, problematize seemingly clear-cut dichotomies and unwrap how concepts like religion and development are understood and contested by different actors and stakeholders, their micro-approach also has its limitations (Bolotta et al., 2019).

Some scholars have pointed out that many publications in this field have a positive bias, to the point of framing FBOs as 'a missing element in the development puzzle' (Hoffstaedter and Tittensor, 2014, p.403; Tomalin, 2012). A wide range of virtues are attributed to faith-based actors, demonstrating their capacity for more effective, efficient and relevant development work. FBOs are applauded for, among other things: their attention to holistic development, incorporating moral and spiritual aspects of well-being, as an alternative to mainstream (secular) development; their capacity to engender trust, legitimacy and commitment, and to motivate and mobilize donors, volunteers, staff, and communities; their cultural proximity and responsiveness to poor communities; their long-established local and international networks, facilitating effective and efficient service delivery, ... (ibid; Heist and Cnaan, 2016; Leurs, 2012). However, this focus on the distinctiveness and comparative advantages of FBOs does not seem to be backed up sufficiently by empirical evidence. According to Tomalin (2012), most benefits that supposedly distinguish FBOs from their secular counterparts, have to do more with aspects of embeddedness and (in)formality in relation to communities than their religious identity. Furthermore, the tendency in the literature to commend faith-based development is reflected in the relatively sparse attention given to critiques of FBOs, and the risks of incorporating religion in development in general. Possible drawbacks like proselytism, preferences for same-faith beneficiaries (and the exclusion of others), and the conservative or roundabout handling of issues like gender and sexuality, are often mentioned, but rarely examined in depth (e.g. James, 2011).

\section{Research question and methodology}

Considering that faith-based development organizations integrate their religious identity in various ways and degrees, and that they do not hold the monopoly to specific 
strengths, this article aims to contribute to a better empirical understanding of how incorporating religion in development cooperation can be both beneficial and risky. To this purpose, this article not only addresses how religious characteristics shape the ideas and practices of faith-based NGOs (as proposed by Ware et al., 2016), but also how NGOs, faith-based or not, take into account religion as a given in the development field. Notwithstanding the earlier disregard for religion in academic and development policy circles, on the ground many NGOs have been giving religion a place in their development practice, by choice or necessity. For some NGOs religion is a part of their own identity as an FBO, whereas most or even all NGOs, faith-based or not, will have to deal with religious aspects of the contexts in which they operate.

This article focuses on how (representatives) of Belgian NGOs perceive the various ways in which they give a place to religion in their development practice. It offers a tentative exploration of the following research question: how do development practitioners perceive the significance of religion for the effectiveness and sustainability of development cooperation? In the context of this study, religion refers to the identity of development cooperation agencies, as well as to characteristics of communities and contexts in the global South where NGOs operate. Focusing on an empirical approach, this study is based on semi-structured interviews with representatives of eight Belgian NGOs. Apart from their willingness to cooperate, these particular organizations were selected to reflect the diversity of the ways religion plays a role in NGOs' development practice. The selection was discussed beforehand with the federation of Belgian NGOs. Every interview was held face-to-face at the NGO's headquarters with one or more spokespersons of the NGO expressing their views and experiences on following topics:

- the position and importance given to religion, within the NGO itself and regarding its partners and stakeholders

- religious elements or characteristics in relation to aid effectiveness and sustainability

- to what extent and in what ways the local religious context is taken into account

- possible tensions originating from religious elements in the target group and/or the NGO itself

- how religion is considered in day-to-day practice on ground level

The interviews took place during January 2018 with representatives of following organizations: Broederlijk Delen, DISOP, Fracarita Belgium, Karama Solidarity, SOS Kinderdorpen, Tearfund Belgium, Via Don Bosco, and Viva Salud. Presently, three of these organizations (Fracarita, DISOP and Karama Solidarity) do not have NGO status according to Belgian law, which excludes them from co-financing by the federal government. However, in all other respects they operate like other Belgian NGOs. Furthermore, the gathered data were triangulated through 
supplementary interviews with the leadership of the federation of Belgian NGOs, and two academic experts. ${ }^{1}$

Notwithstanding the explorative nature of this research, we have to acknowledge its methodological limitations. These are largely due to time and budget constraints. First, only eight NGOs were selected, reaching nowhere near a representative sample of Belgian - let alone European - NGOs. Nevertheless, the sample aims to comprise a broad spectrum of gradations of religiosity, varying from non-religious to strongly faith-based. While Belgium is a mostly secularized Roman Catholic country, also Evangelical (Tearfund) and Muslim (Karama Solidarity) NGOs were selected, as well as secular NGOs operating in localities where religion is a dominant factor in public life. Second, the findings of these interviews have to be qualified as perceived facts rather than verified facts. While the researchers made an effort to triangulate these outcomes with other sources, it must be acknowledged that most data were obtained from the actors themselves.

\section{Introducing the interviewed NGOs}

Table 1 provides an overview of the interviewed NGOs, presenting some main characteristics, including how they either assume a religious identity, or encounter religion through their support constituencies and partnerships.

As far as the available and gathered data allow, the NGOs in Table 1 have been tentatively ranked according to the 'pervasiveness' of religiosity (Berger, 2003), taking into account not only their self-ascribed organizational identity, but also the characteristics of their partners in the Global South and their support constituencies in Belgium. The first five NGOs are more or less on par and can be considered faith-based organizations (FBOs), which we consider as a subset of NGOs (Clarke and Ware, 2015, p.43), and can be defined as 'non-governmental organisations that define themselves as religious, either by referring to religion in their name, or by referring to religious principles, traditions, practices, authorities, figures or concepts in relation to their rationale, activities, staff, funding sources, or target groups' (Le Moigne and Petersen 2016, p.12). Three of them (Tearfund, Fracarita Belgium, Via Don Bosco) work exclusively through their own network of homologue branches overseas. While embracing its Christian inspiration, the sixth NGO (Broederlijk Delen) has evolved into a pluralistic approach, with only its traditional constituencies still giving a Catholic flavour to the organization. By their own account, none of these organizations resort to proselytism under the banner of development cooperation. The two remaining organizations

$1 \mathrm{We}$ are grateful to Katrijn Declerck and Jan Decoene (Fracarita Belgium), Filip Lammens (Via Don Bosco), Cecil Van Maelsaeke (Tearfund Belgium), Stijn Raes (SOS Kinderdorpen), Wim De Ceuckelaire (Viva Salud/G3W), Gerard Verhelst (DISOP), Brigitte Herremans (Broederlijk Delen) and Ahmed Bouzianne (Karama Solidarity). We also thank Arnout Justaert and Johan Cottenie (NGO Federatie), Dick Houtman (Faculty of Social Sciences, KU Leuven), and Kim Christiaens (KADOC, KU Leuven). 


\begin{tabular}{|c|c|c|c|c|c|c|}
\hline Name & Background & Identity & Staff* & Domain of activities & Type of partners & Constituency \\
\hline $\begin{array}{l}\text { Tearfund } \\
\text { Belgium }\end{array}$ & $\begin{array}{c}\text { Tearfund UK }\left({ }^{\circ} 1965,\right. \\
\text { Biafra War })\end{array}$ & $\begin{array}{l}\text { Evangelical } \\
\text { (FBO) }\end{array}$ & $\begin{array}{c}10 \\
(\mathrm{HQ}: 5)\end{array}$ & $\begin{array}{l}\text { Structural aid, vulnerable } \\
\text { groups (health } \& \\
\text { education) }\end{array}$ & $\begin{array}{c}\text { Tearfund network } \\
\text { (Afr.; Lat.Am.; Serbia) }\end{array}$ & $\begin{array}{l}\text { Belgian Evangelical } \\
\text { communities }\end{array}$ \\
\hline $\begin{array}{l}\text { Karama } \\
\text { Solidarity }\end{array}$ & $\begin{array}{c}\text { Islamic Relief Worldwide } \\
\left({ }^{\circ} 1984, \mathrm{UK}\right)\end{array}$ & $\begin{array}{l}\text { Islamic } \\
(\mathrm{FBO})\end{array}$ & $\begin{array}{c}12 \\
(\mathrm{HQ}: 12)\end{array}$ & $\begin{array}{c}\text { Humanitarian \& } \\
\text { structural aid (local } \\
\text { development) }\end{array}$ & $\begin{array}{l}\text { Informal network local } \\
\text { partners (Asia, Africa) }\end{array}$ & $\begin{array}{c}\text { Belgian Muslims (zakat } \\
\text { valorization) }\end{array}$ \\
\hline DISOP & $\begin{array}{l}\text { Belgian congregation } \\
\text { Fathers of the Holy Heart } \\
\quad\left({ }^{\circ} 1961, \text { Brazil }\right)\end{array}$ & $\begin{array}{l}\text { Catholic } \\
\text { (FBO) }\end{array}$ & 8 (HQ:5) & $\begin{array}{l}\text { Structural aid, vulnerable } \\
\text { groups (rural } \\
\text { development, micro- } \\
\text { credit etc.) }\end{array}$ & $\begin{array}{c}\text { Local partners } \\
\text { (Catholic } \\
\text { organizations, Afr. \& } \\
\text { Lat.Am.) }\end{array}$ & $\begin{array}{l}\text { Donors within Catholic } \\
\text { church \& sympathizers } \\
\text { (private sector) }\end{array}$ \\
\hline $\begin{array}{l}\text { Fracarita } \\
\text { Belgium }\end{array}$ & $\begin{array}{l}\text { Brothers of Charity } \\
\text { congregation } \\
\text { (international network } \\
\text { mental health care) }\end{array}$ & $\begin{array}{l}\text { Catholic } \\
\text { (FBO) }\end{array}$ & $\begin{array}{c}11 \\
(\mathrm{HQ}: 10)\end{array}$ & $\begin{array}{c}\text { Structural aid (mental \& } \\
\text { disabled health care, } \\
\text { education) }\end{array}$ & $\begin{array}{c}\text { Fracarita network } \\
\text { (focus on Central } \\
\text { Africa) }\end{array}$ & $\begin{array}{c}\text { Staff, students, } \\
\text { congregation and } \\
\text { entourage of Brothers of } \\
\text { Charity institutions }\end{array}$ \\
\hline Via Don Bosco & $\begin{array}{l}\text { Salesian congregation } \\
\text { (Don Bosco schools) }\end{array}$ & $\begin{array}{l}\text { Catholic } \\
\text { (FBO) }\end{array}$ & $\begin{array}{c}21 \\
(\mathrm{HQ}: 20)\end{array}$ & $\begin{array}{c}\text { Structural aid (education, } \\
\text { TVET) }\end{array}$ & $\begin{array}{l}\text { Don Bosco network } \\
\text { (Africa \& Lat.Am.) }\end{array}$ & $\begin{array}{c}\text { Staff, students, } \\
\text { congregation and } \\
\text { entourage of Don Bosco } \\
\text { schools }\end{array}$ \\
\hline $\begin{array}{l}\text { Broederlijk } \\
\text { Delen }\end{array}$ & $\begin{array}{c}\text { Origin: episcopal aid } \\
\text { agency }\left({ }^{\circ} 1961, \text { Kasai }\right. \\
\text { famine, DRC) }\end{array}$ & Christian & $\begin{array}{c}63 \\
(\mathrm{HQ}: 32)\end{array}$ & $\begin{array}{c}\text { Structural aid (advocacy } \\
\text { \& community } \\
\text { development) }\end{array}$ & $\begin{array}{c}\text { Local partners } \\
\text { (pluralistic; Africa, } \\
\text { Lat.Am. \& Palestine) }\end{array}$ & $\begin{array}{c}\text { Catholic parishes } \\
\text { (national fundraising } \\
\text { campaigns) }\end{array}$ \\
\hline $\begin{array}{l}\text { SOS Kinder- } \\
\text { dorpen }\end{array}$ & $\begin{array}{c}\text { Post-war philanthropy }\left({ }^{\circ}\right. \\
1946 \text {, Austria) }\end{array}$ & Pluralistic & $\begin{array}{c}70 \\
(\mathrm{HQ}: 16)\end{array}$ & $\begin{array}{c}\text { Structural aid (care \& } \\
\text { education for orphans) }\end{array}$ & $\begin{array}{l}\text { SOS network (focusing } \\
\text { on West-Africa) }\end{array}$ & $\begin{array}{l}\text { Corporate, private and } \\
\text { institutional donors }\end{array}$ \\
\hline $\begin{array}{l}\text { Viva Salud } \\
\text { (previously } \\
\text { G3W) }\end{array}$ & $\begin{array}{l}\text { Medicine for the People } \\
\text { (Marxist-Leninist } \\
\text { movement, 1970s) }\end{array}$ & Marxist & $\begin{array}{c}17 \\
(\mathrm{HQ}: 15)\end{array}$ & $\begin{array}{c}\text { Structural aid } \\
\text { (community } \\
\text { development, advocacy) }\end{array}$ & $\begin{array}{c}\text { Local partners } \\
\text { (Marxist; DRC, } \\
\text { Philippines, Cuba, } \\
\text { Palestine) }\end{array}$ & $\begin{array}{l}\text { Marxist-Leninist } \\
\text { movement }\end{array}$ \\
\hline
\end{tabular}

Table 1: Selected NGOs: religious and other characteristics.

* Number of staff is not expressed in number of FTE but people on the payroll, with staff based at headquarters between brackets. Note that some organizations have projects in the South run by their own staff, while others mainly operate through partners' staff. 
(SOS Kinderdorpen, Viva Salud) have neither a religious identity, nor a religious origin. They operate, however, in contexts where religion is a key factor in public as well as in people's private life. In the following, these eight NGOs are briefly introduced, showing how religion is relevant for them.

Tearfund (The Evangelical Alliance Relief Fund) is an international NGO catering for Evangelical communities worldwide. It brings the Christian doctrine in practice by supporting vulnerable groups on their path to self-reliance through education and health care initiatives. With origins in missionary work, Tearfund was founded as a fundraising bureau at the time when spiritual activities became combined with humanitarian aid, particularly in response to the Biafra war and the subsequent famine in 1965. Donations for Tearfund Belgium (starting from 1979) are channelled to local partners, which are mostly church-linked NGOs. Expats usually have strong ties with their Evangelical community at home. Tearfund maintains that, while its vision on development combines the material with the spiritual, it caters for communities rather than specific target groups, and every beneficiary's faith is respected.

Karama Solidarity (originally Islamic Relief Belgium) belongs to Islamic Relief Worldwide, a network founded in 1984 with its headquarters in Birmingham, UK. The organization changed its name to avoid confusion with Islamic Relief International (Saudi-Arabia), which operates on the basis of the dawah commandment (Islam proselytism). In contrast, Islamic Relief Worldwide organizations like Karama Solidarity work through the zakat obligation (alms-giving). Karama Solidarity collects nearly all of its donations from Belgian Muslims. It supports beneficiaries in 33 countries in Asia and Africa through water and sanitation projects, health services, education and income-generating activities, for which partner organizations are capacitated. Selfreliance and participative approaches are key concepts in Karama Solidarity's development approach.

DISOP is an NGO with missionary origins. It was founded in 1961 to raise funds for a project by one of the Fathers of the Holy Heart in Francisco Beltraõ, Brazil. In the spirit of the Second Vatican Council, European churches were asked to support Latin American churches during times of political distress and dictatorship. DISOP evolved from being an intermediary between base communities and European Catholic NGOs (e.g. Misereor, Entr'aide, Lutte contre la Faim), into a full-fledged NGO. By 2014, it was involved in 100 partnerships in 20 countries, most of them supporting vulnerable groups in rural contexts with micro-credit, entrepreneurship and housing projects. Relying on institutional donors, DISOP is not a campaigning NGO. It incorporates a Christian personalist vision on development, stressing personal responsibility, self-reliance and solidarity. Personal development and religious education are seen as a continuum. Local partners are mostly clerical institutions and parish priests.

The Brothers of Charity have a long history of providing mental healthcare in Belgium. Since 1967, this Catholic congregation is also active as the Fracarita International network, consisting of NGOs in European, African and Asian countries. At present, Fracarita Belgium has projects in 19 Asian and African countries. With a 
strong focus on mental healthcare, care for the disabled, and education, its projects are embedded in local Brothers of Charity institutions. Funds mostly originate from the Brothers of Charity communities in Belgium. Fracarita claims to fight all forms of injustice, inspired by an activist view of Christianity, and a sensitivity for poverty and exclusion. Setting up a worldwide network of like-minded institutions is considered the most effective way to put this commitment in practice.

The Salesian Congregation of Don Bosco has an equally long history of global networking, notably in the domain of vocational training. Out of the Belgian Salesians' missionary legacy emerged the NGO Via Don Bosco, which designs projects of vocational education and labour market insertion. Their overseas partners are not the Don Bosco schools themselves (in Africa and Latin America), but the Salesian Development Offices serving those schools. Funds are raised from Belgian Don Bosco school communities and their entourage, private donors, and the public at large through national campaigning. The Salesian vision on development combines 'education through skilling' with 'education through meaning', with the focus on values, rights and social change. According to Via Don Bosco, these values are not necessarily coined in traditional Christian terms.

Broederlijk Delen, one of the largest Belgian NGOs, started in 1961 when Catholic parishes collected funds for famine relief in the Kasai region (DRC). Presently, the NGO emphasizes structural aid, with a focus on capacitating, lobbying and advocating for vulnerable groups, often in a rural context. Their annual fundraising campaign during Lent (Vastenactie) addresses the public and large private donors, apart from their traditional ageing parish-based constituencies. While the Catholic hierarchy still has a seat at the table, Broederlijk Delen is not expected to express the views of the Church. Nevertheless, they still find inspiration in papal encyclical publications such as Laudatio Si (2015), pleading for a more ecological lifestyle. The partners of Broeder Delen, mostly service NGOs who cater for local communities, are not necessarily sought among religious organizations. The NGO stresses the importance of shared universalistic values, human rights and pluralism. For example, none of their partners in Palestine carries an exclusive Muslim, Christian or Jewish signature.

Contrary to these NGOs, SOS Kinderdorpen does not have a religious background or identity. Nevertheless, it operates in contexts where religion is a key factor in public as well as in people's private life. Originating in 1946 when Austrian philanthropists decided to focus on war orphans, this NGO is still committed to the wellbeing of children who lost, or are at risk of losing, parental care. Grown into an international network of 134 autonomous national NGOs, they presently have a joint outreach of 80,000 children in so-called children villages, and 700,000 children in family strengthening programmes. While SOS Kinderdorpen Belgium has domestic programmes (e.g. for unaccompanied minor refugees in Belgium), it is mainly active in the South. For instance, it is presently providing humanitarian aid in Syria, as well as running a talibé programme in Mali and Senegal. The latter targets children who were send to Quranic schools by their poor parents to receive shelter and education, but ended up 
being forced to go out begging to compensate for food and lodging. SOS Kinderdorpen's programme aims to establish a relationship of trust with Islamic clergy to allow the children to be sent to community schools.

Finally, Viva Salud (previously G3W, Medicine for the Third World) is an offshoot of GVHV (Medicine for the People), which is situated in the Belgian Marxist-Leninist movement. Established in the late 1980s, Viva Salud used to send GVHV-affiliated physicians to befriended organizations in the South. Currently, its focus has shifted to a more political health rights approach: through advocacy and mobilization they aim to create a counterforce claiming legitimate rights. Viva Salud has partners in Cuba, the Philippines, the DRC and Palestine. By their own account, the NGO understands religion as a cultural feature that deserves respect, however without incorporating it in its theory of change. Partners are supposed to be pluralistic, i.e. not excluding groups according to gender, race or religion.

This overview shows that NGOs relate to religion in many ways. Firstly, NGOs themselves can have religious dimensions, even to the point of being faith-based. Organizations may uphold a self-ascribed religious identity, possibly inserting religious elements in their activities at home and abroad. They may have religious origins, belong to a congregation, or strongly rely on religiously defined constituencies. Secondly, religion is almost always a factor in the context in which NGOs operate. The religious beliefs of target groups and their societal context, as well as local partners' ideological identity, will always come into play. To better understand the significance of religion for development cooperation, it is worthwhile exploring how these elements unfold in the actual practice of development. In the following, this article will present how the selected NGOs perceive and experience both the positive, enabling significance of incorporating the abovementioned religious dimension in development practice, as well as some challenges.

\section{Incorporating religion as an asset for development cooperation}

At the outset, this empirical study set out to unpack the experiences and perceptions of a sample of Belgian NGOs regarding three questions: (a) is being a religious NGO an asset or rather a challenge, and how? (b) in which ways can a religious local context be favourable, or rather disadvantageous, for deploying development activities effectively? And (c) does it help to have a religious identity to operate in a religious context in the South? However, during analysis it became clear that these questions were so interconnected, that they could not be summarized separately. Instead, we have opted to first highlight the ways in which our interlocutors have experienced religion as an asset for development work. Afterwards we will present perceived challenges in this regard. Still, their testimonies often acknowledge that strengths can hold risks too, and challenges can be coped with.

A first possible strength of religiously embedded development is mentioned especially by representatives of FBOs: the religious motive is said to be authentic 
and thus strengthens the legitimacy of development cooperation as implemented by religious NGOs. This claim is most prominent amongst congregation-based NGOs such as Fracarita and Via Don Bosco. For Fracarita, its overseas work is based on the apostolate, not to preach the word but to help those who are suffering. Via Don Bosco puts forward the central importance of 'meaning' within its emancipatory and educational efforts: 'Development should be oriented towards social change in which the whole person is addressed, including values such as freedom, responsibility, connectedness and meaning.' Although its development activities have no religious goals in the narrow sense, the realization of values is paramount: 'We do not hide our Catholic inspiration - our Salesians also have an input in our annual refreshment courses for teachers, notably in the sections about values and meaning.' Accordingly, it is suggested, this religious inspiration adds something to secular motives and values most NGOs appeal to (solidarity, self-reliance, human rights). As a consequence, FBOs may be perceived as more authentic and legitimate, especially by likeminded potential benefactors and religiously inspired segments of the public.

At least five of the eight NGOs claim they manage to mobilize a large constituency because of religion-related reasons (Tearfund, Karama Solidarity, Fracarita, Via Don Bosco and Broederlijk Delen). For them, campaigning holds an appeal to groups who are more easily reached because they share the same religious beliefs or belong to the same religiously defined community. These NGOs not only benefit from existing channels of communication, but in some cases even attach recurring fundraising campaigns to appropriate religious events (e.g. Lent for Broederlijk Delen, Ramadan and Feast of the Sacrifice for Karama Solidarity). Interpersonal connections also contribute to the trust and commitment of their constituencies, as exemplified by Tearfund:

Our expats usually have close ties with the Evangelical community they belong to here in Belgium, while our partners in the South are often directly connected with a local Evangelical community. This makes for a smooth North-South communication and therefore a huge credibility of the projects in the eyes of our donators.

In contrast, other NGOs have to put more effort in explaining values and goals to their intended donors. This mobilizing power, however, also seems applicable to highly ideologically driven NGOs such as Viva Salud.

Furthermore, many religious NGOs seem to benefit from committed staff, volunteers and donors who consider it their moral or religious duty to pull their weight. The religious 'packaging' of values and the idea of belonging to a community of like-minded supporters, add to the credibility of the organization. Complex rationales or lengthy explanations are not required. In this sense, Karama Solidarity benefits from the zakat, the obligatory annual donation for every practicing Muslim. Broederlijk Delen and Via Don Bosco have a portfolio of conservative philanthropic donors who would only put their trust (and money) in Catholic organizations. Moreover, the latter two NGOs have remarkably low staff turnover, which is unusual in the NGO 
world. The moral dimension of professional commitment is even mentioned explicitly by Tearfund's representative:

As FBO, we benefit from a vast network of volunteers and the stability of our staff. Our expats consider their commitment as a calling throughout their entire professional career, instead of a short term experience as is often the case elsewhere.

Other narratives suggest that the religious embeddedness also strengthens the dedication of local volunteers, staff and partners in the South. DISOP, for example, mentions that

local clerical structures often demonstrate a sense of responsibility and sustainability, which is not reached at the same level through project-steered NGOs. The unselfish, voluntary contributions by many of our people in the South, make our work effective and therefore legitimate.

In many interviews, another asset of religiously embedded NGOs surfaces: belonging to consolidated international networks contributes to the sustainability of development activities. Via Don Bosco, for example, describes having an established network of trustworthy partners who can take ownership of projects as their strong point. This not only saves on identification and transaction costs, but also increases the likelihood that results last after projects end. This statement was endorsed by Fracarita, whose global congregational structure makes monitoring and oversight more feasible. Religious networks also offer practical advantages: 'Fracarita always tries to get in touch with the local clergy, which often results in gaining free access to their infrastructure and networks. They understand that our expertise also radiates positively on them.' DISOP confirms the advantage its religious background provides for the sustainability of its projects: 'After the donor has departed, the local church will remain accountable to the community for the achievements been made to last.' Tearfund explicitly describes its cooperation with local Evangelical churches as a major asset for its effectiveness: these partners are open to direct communication, provide access to local communities, and enhance sustainability because of their local permanence. At the same time, Tearfund acknowledges that the socio-economic views of some Southern partners are not aligned with Tearfund's. If necessary, Tearfund first starts a process of 'internal capacity development' to adjust these views, before forging the partnership. Though problematic, such paternalism, in which development agencies more or less onesidedly set the epistemological parameters of the partnership, may be inherent of power relationships in the development context (Baaz, 2005).

Being able to rely on local networks of the same faith, can provide religious NGOs a comparative advantage, as is demonstrated by Benthall and Bellion-Jourdan (2009, p.92) in their study of aid in the Muslim world. They refer to Islamic Relief and the Aga Khan Foundation who through their local networks could channel aid to locations that would be inaccessible for either Christian or secular international NGOs. Religious 
NGOs also may have an edge on other NGOs due to shared values and cultural empathy, especially when working with communities of the same faith (Flanigan, 2010; Heist and Cnaan, 2016, pp.5-6). For example, Fracarita claims it is more easily accepted by its partners and beneficiaries since they share the same Christian faith. Similarly and consistent with De Cordier's findings (2009), Karama Solidarity asserts that it does not raise suspicion in heavily Islamized contexts whereas western NGOs definitely do. According to their representative,

in some regions in Asia and the Middle East, the suspicion towards aid workers is high, making it difficult for them to work. As an organization with a clear Islamic profile, we are accepted to a point where we can also bring 'difficult' messages, such as allowing girls to attend school.

A particular example in Pakistan came to mind, where a Western NGO tried in vain to set up a microcredit system. Karama Solidarity adopted the project and introduced it to the local villagers by referring to the Islamic principle of interest-free banking. Though it took time and a lot of deliberation, this approach was fruitful. According to Karama Solidarity, similar processes are successfully being deployed in Afghanistan with regard to girls' schooling: patience, gaining trust of local imams, and referring to Islamic principles which include the right of all children to go to school. However, a common religious framework is equally advantageous for Christian NGOs. According to DISOP, a common religion simplifies the task of motivating Brazilian target groups, for example, by using the biblical story of Moses leading his people to the promised land during a mistica ${ }^{2}$ on farmland occupation by landless peasants. In the experience of Broederlijk Delen, a common religious or spiritual identity can be meaningful in reconciliation projects, such as in post-genocide Rwanda: 'It is known that mutual willingness to listen to each other is much more easily reached through a spiritual approach, than through a psychological (post-traumatic) or judicial approach.' Tearfund on the other hand, gives the example of imams in Burkina Faso who force boys belonging to Quranic schools to go out begging. Tearfund's dialogue with the imams, during which they referred to religious values such as the right of all creatures to lead a worthy life, resulted in the youngsters being allowed to attend regular classes in the afternoon. SOS Kinderdorpen shared very similar experiences regarding their talibé projects in Mali and Senegal:

We were able to gain the trust of the imams thanks to a patient dialogue and referring to common values. Although the religious beliefs of our local staff is not part of the project, this enables a more effective communication with the imams. They know the local religion, the language, and the implicit values.

2 In Latin American social movements, a mistica is a collective ritual expressing the goal and the determination of a collective action, such as the occupation of unattended farmlands by Landless Workers' Movement (MST) in the Brazilian interior. Its roots lie in Christian mysticism and liberation theology (Issa, 2008; Hammond, 2014). 
The last example shows that an NGO does not need to have a religious identity itself to show a religious sensitivity. During a debate between NGOs on the role of religion in development work (Echos Communication, 2015), the representative of Broederlijk Delen stated that the 'language of human rights' is often a barrier to refer to shared values in discussions with religious interlocutors in the South. Other participants in the debate also believed that 'religion could build bridges across seemingly unbridgeable gorges.' Therefore, religious empathy is not the prerogative of FBOs and their same-faith beneficiaries. It can work in an inter-religious set-up too, as well as in the approach used by a secular NGO.

Finally, some of the interviewed NGOs suggest that incorporating religion in the intervention logic allows for a more realistic theory of change. Broederlijk Delen refers explicitly to the Catholic social teachings (the Rerum Novarum encyclical of 1891) as well as the religion-inspired duty to seek normalization and dialogue rather than confrontation. From that perspective, the NGO deliberately selects its partners in Palestine according to their openness for dialogue with Israeli (Jewish) organizations. Fracarita, on the other hand, emphasizes the importance of the spiritual for all aspects of life in Africa, including mental health care:

Mental healthcare, which is our core business, is closely related to religion there. Expats who are based in Africa and are not appreciating the importance of the spiritual for all other life domains, will never be able to develop an effective system of mental healthcare. By providing a spiritual conception of mental dispositions, people are better protected against 'false prophets', such as the Eglises de Reveil ${ }^{3}$ in the DRC, who preach predestination, fate acceptance, and political conservatism.

The narratives of the interviewed NGOs seem to identify two main advantages of giving religion a place in development work: access and leverage. Whether regarding the NGOs' legitimacy, supporting constituency, staff, network, or local stakeholders, having a religious identity and/or taking into account the local religious context, is perceived as an added value.

\section{Challenges and coping strategies related to religion}

These assets may suggest that religion is highly compatible with the institution of development cooperation. However, NGOs also face challenges related to working in a religious context, as well as the challenge of being a religious organization and a development actor at the same time.

A first challenge, or rather suspicion, related to religious NGOs, could be that religious organizations still feature charity aid, without taking into account the structural causes of poverty and injustice. Such aid is often packed as a 'gift' from the donor to the beneficiary, and holds the risk of being donor-driven and paternalistic in style. However, based on our research - and after triangulation - we have not come across 
evidence that religious NGOs would be more paternalistic in their operations than secular NGOs. While the charity 'sphere' is still somehow present in fundraising, for instance in the church-based fundraising of Broederlijk Delen and the zakat donations of Karama Solidarity, the overseas activities of these NGOs focus on capacity building, community development, lobbying and advocacy. The NGO federation leadership confirmed this conclusion: 'Charity is the domain of citizen initiatives, not of NGOs who seek to be subsidized. NGOs, whether religious or non-religious, need to demonstrate a structural approach in order to get public funds.'

Another reproach of which religious NGOs are particularly cautious, dubbed 'the prickliest of subjects' by Fountain (2015), is that their development work represents a continuum with the proselytizing work of (earlier) missionaries. As mentioned before, Karama Solidarity even changed its original name to avoid any suspicion that donations would be funding Islamic proselytism. However, many religious NGOs cherish a holistic vision on development, in which spirituality is essential. This is the case for DISOP, for example: 'For us, it is difficult to see a separation between social development and religious development. As we work towards an integral approach, religion is the common feature of all our activities, whether reflection, discussion or action.' At the same time, DISOP claims it is careful to avoid the appearance of proselytism: 'Especially in Africa, we often do not organize religious education, exactly to avoid the impression that are trying to win souls.' Similarly, Tearfund acknowledges that spiritual and material development are in continuity with each other:

Everyone is entitled to a dignified life, without poverty and injustice. To this purpose, we work on both the outside and the inside, both the material conditions and religious beliefs. The soul is the real catalyst of change, this is our theory of change.

However, by their own account both organizations are very restrictive in their project planning. When it comes to formulating and planning projects, development activities are strictly separated from missionary work, lest they lose their NGO status, which is required to receive co-financing. At the same time, and perhaps problematically, they do not hide that they predominantly collaborate with local churches, which they consider as a guarantee for sustainability. For NGOs like Fracarita and Via Don Bosco, this seems to be less of an issue, since their congregations do not have an outspoken history of missionary activities in the first place. Both organizations explicitly mention that their development activities have no religious goals whatsoever.

A third challenge concerns the profile of the beneficiaries, who may mostly or even exclusively belong to the same religion as the NGO in question. Whereas our interviewees denied this potential criticism and stressed inclusivity, a certain 'orientation' regarding the choice of regions and partners seems to be discernible. Yet, DISOP and Fracarita state that they do not provide (compulsory) religious classes in their schools in African regions where multiple religions co-exist. Karama Solidarity is 
also active in non-Muslim Central Africa. For the sake of inclusiveness, Broederlijk Delen claims to look for partners without a religious profile:

Our partners are connected to local communities experiencing socio-economic marginalization, no matter their religious beliefs. In the Middle East, for example, we'll never work with partners who only cater for minoritized Christian communities, lest this minoritization is confirmed and dialogue hampered. This is a deliberate choice, that sets us apart from Christian NGOs like Misereor or Caritas.'

Tearfund acknowledges that its local partners are usually Evangelical churches, but in a non-exclusive way. It also cooperates with secular organizations, such as the Red Cross and Médecins Sans Frontières in Burkina Faso (for the care of homeless children), and the UN in Myanmar (providing shelter for Rohingya refugees). Additionally, Tearfund has constructed post-earthquake housing for mixed Hindu-Muslim communities in Gujarat, India (2001), as well as water pumps areas in Madagascar where indigenous religions prevail. Finally, a certain orientation also seems discernible in the case of Viva Salud, whose partners and beneficiaries are sought among ideological and political allies in a context that Viva Salud describes as a political conflict. The de facto preference for like-minded beneficiaries may be a common practice among NGOs, religious and secular alike, and relies on the tacit principle that NGOs can establish partnerships at their own discretion, with whom and wherever they deem it necessary.

Regarding the context in which both religious and non-religious NGOs work, traditional religious views may be a conservative factor for communities, especially regarding ethical issues, gender equality and ideological tolerance. The interviewed NGOs claim that they recognize this risk and have developed appropriate coping strategies. These strategies range from pragmatic avoidance, to negotiation, gentle persuasion through dialogue, and sometimes confrontation. A very careful approach is exemplified by DISOP, that claims to be successful by not pushing differences of opinion to the limit:

A development actor should not meddle in local beliefs, but should take it into account out of pragmatism. Our attitude regarding conservative local opinions on gender, contraception and birth control, is not to provoke people or escalate the discussion. It's a delicate balancing act between how we see development and local cultures.

A similar pragmatism can be detected in Broederlijk Delen's policy in Palestine, where it upholds its support for a theatre group (Theatre Productions), even though it sometimes conforms to Hamas' ban on mixed-gender art groups. Likewise, Viva Salud prefers to avoid this subject altogether in its youth programmes in Gaza: instead of insisting that boys and girls join together in artistic workshops, they emphasize the importance of both groups being able to participate, albeit separately. Karama Solidarity's efforts to promote girls' school attendance in rural Afghanistan, illustrate an influence-oriented approach: by patiently explaining to local imams that Islamic principles 
they are familiar with are often contrary to tradition, the NGO has succeeded in turning many of them into staunch supporters of girls' education. Finally, Tearfund seemed to implement a more compelling, compliance-oriented approach, for instance by using girls' school attendance as a conditionality for supporting their partners' projects in Burundi. In other contexts, however, Tearfund takes on a more flexible strategy, especially when the disagreement has more to do with (religious) politics than with local communities' beliefs. In Chennai, India, for example, Tearfund was meeting strong opposition against a project of providing quality education for relocated poor dwellers. Hindu nationalists did not accept lower caste communities being 'privileged' by Tearfund's activities, which resulted in opening up the project to other castes as well. It is worth noting that NGOs also take into account the local context, religious and otherwise, regarding their expectations of expat staff. Fracarita, for example, assumes a compliant attitude in order not to estrange their expats from the local community because of lifestyle differences:

We send married couples to the South, rather than singles, and our expats attend church to show they are practicing Christians. This helps to gain local acceptance. An 'unchristian' lifestyle, like being divorced or openly gay, will be seen as strange, and will not be conducive to collaboration.

Of course, the suitability of each of these coping strategies in their particular context, can be called into question. Nevertheless, it is clear that even religious NGOs cannot afford not to adopt strategies that enable them to work effectively in a particular local context.

Finally, during the interviews also questions of a more paradigmatic nature were brought up, challenging the paradigm in which development cooperation finds it legitimacy. Firstly, the discussion with Karama Solidarity in particular, revealed that the universalist values as assumed in the western world are not self-evidently universal. Selfreliance, pluralism, and the rights-based approach may need a deeper justification in critical circumstances. Some ethical concerns, especially related to gender and sexuality, but also to the relationship between the individual and the collective, are often put in practice differently in different cultures. This reality cannot be simply overruled by referring to heads of states having underwritten the Universal Declaration of Human Rights. To circumvent ideas of moral superiority and inferiority, which can reflect a 'neo-colonial' relationship between donor and recipient, the NGOs and their partners seem to look for common ground by referring not only to human rights, but also to what religious value systems are indicating. For example, both DISOP and Fracarita consider religion as providing a better platform for discussing values than the human rights concept. Moreover, when a consensus is not possible, NGOs sometimes choose to leave issues pending, in order to preserve the conditions for dialogue and mutual respect.

Secondly, religion constitutes a powerful sphere in many people's lives, that has hitherto proven to be resistant to any form of instrumentalization or 'boxing' into a 
transversal theme like gender or the environment. In other words, 'as a mode of engagement, religion is not a variable that is instrumental to development, as if the latter was external to it' (Deneulin and Bano, 2009, p.72). Bringing religion into the discourse of development cooperation, or - more correctly - recognizing religion as a factor in development cooperation, may affect the concept of development itself, as suggested by Rakodi (2012). Regardless, the interviews show that each NGO faces the challenge to determine what place religion (or 'the spiritual', or 'meaning') has within development. The secular NGOs we interviewed (Viva Salud and SOS Kinderdorpen) seem to consider religion mostly as a part of the local culture: it has to be taken into account for development activities to be effective, but is neither a central approach nor a development goal in its own right. Although mostly agreeing with this approach, Broederlijk Delen does accept a place for religious values as inspiration, providing there is room for critical reflection (e.g. regarding the Church's stance on condoms). The NGOs earlier categorized as FBOs, see religion as more central to their understanding of development. For Via Don Bosco, the concept of 'meaning' is key, whether understood in the Christian sense or otherwise. Religiously inspired ideas and values are important for them, also without bringing religion as such to the fore:

Secularization has not made people stop asking questions of meaning. Because of our religious background, or religious 'empathy', we are well placed to bring in that element of meaning. Asking these questions together creates connections between people, and a sense of recognition across borders.

According to Karama Solidarity, development activities aim to bring people closer to their own values, including religious ones. Tearfund considers development as first and foremost taking place inside people's mind, and evolving through collective processes.

\section{Conclusions}

Considering the need for empirical evidence in the emerging field of religion and development, this article explored how development practitioners perceive the significance of incorporating religion in development practice. Above we have discussed a number of advantages and challenges related to giving religion a place in development, as narrated by representatives of eight Belgian NGOs. While most of the selected NGOs have a religious background, a few non-religious NGOs were included. After all, the issue of religion in development does not only regard characteristics, ideas and practices of those 'doing development', but also the cultural contexts and the communities in which they work.

On the whole, the experiences and assessments of the interviewed NGOs correspond with advantages and risks mentioned in the literature (e.g. Leurs, 2012; Tomalin, 2012; Ware et al., 2016). Their narratives often stress potential advantages and positive experiences, while potential risks are mostly said to be avoided or 
mitigated. To a certain extent, these self-perceptions seem to reflect a positive bias found in the literature on FBOs. This may be partly related to the religious identity and/or origins of most interviewed NGOs.

Regarding religion as an asset in development, access and leverage are the keywords of the NGOs' narratives. Giving religion a place in NGOs' identities is said to strengthen legitimacy, trust and commitment, facilitating access to constituencies in the North, as well as actors and beneficiaries in the South. Moreover, the structural embeddedness of congregational NGOs in particular, is described as a strength, enabling efficient service delivery and sustainable ownership by local religious actors. While shared values and cultural empathy with communities in the South seem to give religious NGOs an edge over their secular counterparts in some cases, other examples provide evidence that secular NGOs that acknowledge the importance of religion in the South are also capable of demonstrating the same degree of empathy, patience and respect in order to cope with sensitive issues. The same point can be made regarding the alleged mobilizing power of faithbased NGOs, which may also be a strength of secular NGOs with a strong ideological identity.

Conversely, the study highlighted a number of challenges and how the interviewed NGOs claimed to cope with them. While the association of religious NGOs with charity work is not reflected in the evidence, the issue of proselytism raises some concerns. When NGOs regard spiritual development as a core objective, and mainly operate through local same-faith churches and organizations, the discontinuity with missionary work seems less than absolute. Proselytism, or the perception thereof, may not only hinder development efforts in communities with different beliefs, but also jeopardizes official NGO status, and thus the possibility of receiving government co-financing. The interviewed religious NGOs claim to cope with this 'overlap' by strictly separating their religious rationales from their accountability structures (activities, outputs, budgets). Similarly, the potential criticism that religious NGOs favour same-faith beneficiaries is repudiated by narratives of deliberate attempts to avoid exclusivity. Nevertheless, we discern a tendency to focus on like-minded beneficiary groups, also in the case of secular NGOs with a strong ideological line. Furthermore, the interviews revealed various strategies adopted by both religious and secular NGOs to deal with traditional religious beliefs, especially regarding sexuality, gender, and social equality. Whether by choosing to avoid conflict, to negotiate, to try to influence, or to challenge local norms and values, the interviewed NGOs seem to be guided mostly by careful pragmatism. More fundamentally, the universalism of values and principles underpinning the development paradigm itself, like human rights, self-reliance, and pluralism, is sometimes called into question. By their own account, the interviewed NGOs prefer to find at least some common ground with local stakeholders' religious value systems, or even to leave discord unresolved, instead of jeopardizing relationships by claiming the moral high ground. On the paradigmatic level, the NGOs' narratives show various ways of incorporating religion in their conceptualization of development, from nothing more 
than a contextual characteristic to be taken into account, to an essential aspect of human well-being that should be integral to any development rationale.

To some extent these findings question the empirical validity of the dichotomy between faith-based and secular NGOs, especially regarding the focus on comparative advantages and distinctive differences. While this binary opposition is widespread and even adopted by the most reluctant researchers (see Ware et al., 2016, pp.322-323), more nuance and less contrast are needed. As illustrated above, religious and secular NGOs may share some potential strengths and challenges, depending on the particular context and modus operandi. Even the criticism of proselytization may be a shared one, as 'both secular and faith-based organizations are engaged in some form of conversion,' 'aiming to transform the way people in developing countries think and operate,' with 'some faith-based organizations [adding] a faith-element while others do not' (Heist and Cnaan, 2016, p.12). Moreover, religious NGOs do not have the monopoly on challenging mainstream development paradigms by highlighting social and spiritual needs, nor are they all doing so (Tomalin, 2012, p.698). However, the claim that 'the distinction between faith-based and secular organizations may not be useful in contexts where religion permeates almost all aspects of people's lives' (ibid., p.700) does not seem empirically justified either. As far as our analysis allows for comparison, religious NGOs' particular attention for spirituality and religion do influence their everyday practice and relationships with local partners and communities, at least by their own account.

By interviewing a sample of NGOs, we aimed to provide an empirical and groundlevel understanding of what it means for these actors to give religion a place in development. However, these narratives do not allow for factual conclusions on the added value of FBOs in development, or the benefits of inserting religion into development practice as a silver bullet. What is more, while benefits of engaging with religion are acknowledged, an intentional instrumentalization of religion in function of efficiency, effectiveness and sustainability, is completely absent in the NGOs' narratives, religious and secular alike. For the interviewed religious NGOs in particular, religion does not seem to be a 'development strategy' or, even worse, some form of 'window-dressing', but an intrinsically meaningful part of their identity and functioning. However, engaging with communities' religious views and values in a genuine and authentic manner, which is likely to be more effective than instrumentalizing approaches, does not require NGOs and other development organizations to share these beliefs or have any religious inspiration (Clarke, 2014, p.6-7). For this reason, religion in development should not primarily be understood in terms of "typologies [presuming] that religious NGOs operate on a distinctly and uniquely "religious" spectrum which is definitely separated from the spectrums of other non-religious NGOs;' resulting in the construction of 'a field of study - that of "religious NGOs" - which is distinct from the world of secular development' (Fountain and Petersen, 2018, p.417). As Feener et al. (2015) suggest, religion should not be seen as a static, monolithic category, but rather as a 'moving target' that can be best examined in all its variety and specificity 'across 
complex and ever-shifting landscapes' through meticulous empirical research. Detailed ethnographic case studies are particularly suited to provide contextualized insight into the real life manifestations of religion in development. However, in the above we have attempted to do the same by means of examining the narratives of development actors themselves.

\section{AUTHORS}

Ignace Pollet is a sociologist specialized in the organizational analysis of development partnerships. He works at HIVA KU Leuven (Research Institute for Work and Society). In the past he contributed to studies on cooperativism in Africa, meta-evaluations of ILO programmes on employment and social economy, and the intercultural aspects of North-South collaboration.

Benjamin Steegen is a $\mathrm{PhD}$ candidate at the history department of KU Leuven. His research focuses on tensions between discourse, practice and representation in development cooperation, by means of the case study of Belgian missionaries doing development work in postcolonial India.

Idesbald Goddeeris is a professor of history at KU Leuven, where he teaches, inter alia, courses on colonial and postcolonial history. His research focuses on social movements, missionaries, and postcolonial memories in the post-war era.

\section{References}

Baaz, M. E., 2005, The Paternalism of Partnership: A Postcolonial Reading of Identity in Development Aid, London: Zed Books.

Benthall, J. and J. Bellion-Jourdan, 2009, The Charitable Crescent. Politics of Aid in the Muslim World, London: I.B. Tauris.

Berger, J., 2003, 'Religious nongovernmental organizations: An exploratory analysis', Voluntas: International Journal of Voluntary and Nonprofit Organizations, Vol. 14, No. 1, pp. 15-39.

Bolotta, G., C. Scheer and R. M. Feener, 2019, 'Translating religion and development: Emerging perspectives from critical ethnographies of faith-based organizations', Progress in Development Studies, Vol. 19, No. 4, pp. 243-263.

Bornstein, E., 2003, The Spirit of Development: Protestant NGOs, Morality, and Economics in Zimbabwe, New York: Routledge.

Carbonnier, G. (2013), 'Religion and development: Reconsidering secularism as the norm'. International Development Policy/Revue Internationale de Politique de Développement, Vol. 4, No. 1, pp. 1-5.

Clarke, M., ed. 2014, Handbook of Research on Development and Religion, Cheltenham/ Northampton: Edward Elgar.

Clarke, M. and V.-A. Ware, 2015, 'Understanding faith-based organisations: How FBOs are contrasted with NGOs in international development literature', Progress in Development Studies, Vol. 15, No. 1, pp. 37-48.

Dalton, A. M., 2013, 'Beyond functionality: Religion and international development', Canadian Journal of Development Studies/Revue Canadienne D'études du Développement, Vol. 34, No. 2, pp. 158-174. 
De Cordier, B., 2009, 'Faith-based aid, globalization and the humanitarian frontline: An analysis of western-based Muslim aid organisations', Disasters, Vol. 33, pp. 608-628.

Deneulin, S. and M. Bano, 2009, Religion in Development: Rewriting the Secular Script, London: Zed Books.

Deneulin, S. and C. Rakodi, 2011, 'Revisiting religion: Development studies thirty years on', World Development, Vol. 39, No. 1, pp. 45-54.

Echos Communication, 2015, Conference Report 'Religion Anti/pro Development', Brussels October 7th 2015 - cfr http://echoscommunication.org/nl/2015/10/07/verslagontwikkelingsdebat-religie-antipro-ontwikkeling/

Feener, R. M., P. Fountain and R. Bush, 2015, Outlook: Research on religion and development, in P. Fountain, R. Bush and R.M. Feener, ed, Religion and the Politics of Development, New York: Palgrave Macmillan, pp. 243-245.

Flanigan, S. T., 2010, For the Love of God: NGOs and Religious Identity in a Violent World, Sterling: Kumarian Press.

Fountain, P., 2015, 'Proselytizing development', in E. Tomalin, ed, The Routledge Handbook of Religions and Global Development, New York: Routledge, pp. 80-97.

Fountain, P., R. Bush and R. M. Feener, eds, 2015, Religion and the Politics of Development, New York: Palgrave Macmillan.

Fountain, P. and R. M. Feener, 2017, 'Navigating a world of religious NGOs: Ethnography, abstraction, and views from the horizon', Geography Compass, Vol. 11, No. 10, pp. 1-11.

Fountain, P. and M. J. Petersen, 2018, NGOs and religion: Instrumentalisation and its discontents, in A.J. Kellow and H. Murphy-Gregory eds, Handbook of Research on NGOs, Cheltenham/Northampton: Edward Elgar, pp. 404-432.

Freeman, D., 2019, Tearfund and the Quest for Faith-Based Development, New York: Routledge.

Hammond, J. L., 2014, 'Mística, meaning and popular education in the Brazilian landless workers movement', Interface, Vol. 6, No. 1, pp. 372-391.

Heist, D. and R. Cnaan, 2016, 'Faith-Based international development work: A review', Religions, Vol. 7, No. 19, pp. 1-19.

Hoffstaedter, G. and D. Tittensor, 2014, Religion and development: Prospects and pitfalls of faith-based organizatons, in M. Clarke, ed, Handbook of Research on Development and Religion, Cheltenham/Northampton: Edward Elgar Publishing, pp. 402-412.

Huang, J., 2009, Charisma and Compassion: Chen Yen and the Buddhist Tzu Chi Movement, Cambridge: Harvard University Press. Massachusetts.

Issa, D., 2008, Praxis of empowerment: Mística and mobilization in Brazil's landless rural workers' movement, in R. Stahler-Sholk, H.E. Vanden and G.D. Kuecker, ed, Latin American Social Movements in the Twenty-First Century: Resistance, Power and Democracy, New York: Rowman \& Littlefield, pp. 131-145.

James, R., 2011, 'Handle with care: Engaging with faith-based organisations in development', Development in Practice, Vol. 21, No. 1, pp. 109-117.

Jones, B. and M. J. Petersen, 2011, 'Instrumental, narrow, normative? Reviewing recent work on religion and development', Third World Quarterly, Vol. 32, No. 7, pp. 1291-1306.

Karam, A., ed, 2012, Religion, development and the United Nations, https://s3.amazonaws.com/ ssrc-cdn1/crmuploads/new_publication_3/religion-development-and-the-united-nations.pdf.

Karam, A., ed, 2014, Religion and development post-2015. Report of a consultation among donor organizations, United Nations development agencies and faith-based organizations, https:// www.unfpa.org/sites/default/files/pub-pdf/DONOR-UN-FBO\%20May\%202014.pdf.

Leer-Helgesen, A., 2019, Negotiating Religion and Development: Identity Construction and Contention in Bolivia, New York: Routledge. 
Le Moigne, J. and M. J. Petersen, 2016, Donor Engagement with Religion and Faith-Based Organisations in Development Cooperation, Copenhagen: Network for Religion and Development.

Leurs, R., 2012, 'Are faith-based organisations distinctive? Comparing religious and secular NGOs in Nigeria', Development in Practice, Vol. 22, No. 5-6, pp. 704-720.

Marshall, K., 2001, 'Development and religion: A different lens on development debates', Peabody Journal of Education, Vol. 76, No. 3-4, pp. 339-375.

Narayan, D., R. Chambers, M. K. Shah and P. Petesch, 2000, Voices of the Poor: Crying out for Change, New York: Oxford University Press.

Occhipinti, L. A., 2015, Faith-based organisations and development, in E. Tomalin, ed, The Routledge Handbook of Religions and Global Development, New York: Routledge, pp. 331-345.

PEW Research Center, 2015, The Future of World Religions: Population Growth Projections 2010-2050, www.pewforum.org/2015/04/02/religious-projections-2010-2050.

Quarles van Ufford, P. and M. Schoffeleers, eds, 1988, Religion and Development: Towards an Integrated Approach, Amsterdam: Free University Press.

Rajkobal, P., 2019, The Sarvodaya Movement: Holistic Development and Risk Governance in Sri Lanka, New York: Routledge.

Rakodi, C., 2011, 'A guide to analysing the relationships between religion and development', in Religions and Development Research Programme, Working Paper, No. 67, University of Birmingham, Birmingham.

Rakodi, C., 2012, 'A framework for analysing the links between religion and development', Development in Practice, Vol. 22, No. 5-6, pp. 634-650.

Rakodi, C., 2019, Religion and Society in Sub-Saharan Africa and Southern Asia, New York: Routledge.

Scherz, C., 2014, Having People, Having Heart: Charity, Sustainable Development, and Problems of Dependence in Central Uganda, London/Chicago: University of Chicago Press.

Swart, I. and E. Nell, 2016, 'Religion and development: The rise of a bibliography', HTS Teologiese Studies, Vol. 72, No. 4, pp. a3862.

Thaut, L. C., 2009, 'The role of faith in Christian faith-based humanitarian agencies: Constructing the taxonomy', VOLUNTAS: International Journal of Voluntary and Nonprofit Organizations, Vol. 20, No. 4, pp. 319-350.

Tomalin, E., 2012, 'Thinking about faith-based organisations in development: Where have we got to and what next?', Development in Practice, Vol. 22, No. 5-6, pp. 689-703.

Tomalin, E., 2013, Religions and Development, New York: Routledge.

Tomalin, E., ed, 2015, The Routledge Handbook of Religions and Global Development, New York: Routledge.

Ver Beek, K. A., 2000, “'Spirituality: A development taboo', Development in Practice, Vol. 10, No. 1, pp. 31-43.

Ware, A. and M. Clarke, eds, 2016, Development Across Faith Boundaries, Abingdon: Routledge. Ware, V.-A., A. Ware and M. Clarke, 2016, 'Domains of faith impact: How "faith" is perceived to shape faith-based international development organisations', Development in Practice, Vol. 26, No. 3, pp. 312-333.

Wilbur, C. and K. Jameson, 1980, 'Religious values and social limits to development', World Development, Vol. 8, No. 7-8, pp. 467-479. 